\title{
Source Apportionment of Ambient Volatile Organic Compounds from Petroleum and Non-Petroleum Emissions
}

\section{Hai GUO*}

Department of Civil and Environmental Engineering, The Hong Kong Polytechnic University, Hong Kong

Volatile Organic Compounds (VOCs), precursors of photochemical smog and toxic substances, have attracted widespread attention of environmental communities for decades [1]. Petroleum products are often considered as the major sources of VOCs in the atmosphere. However, some VOCs may be emitted from non-petroleum products such as biogenic emissions and biomass burning. Hence, identification of emission sources and quantification of source contributions to ambient VOCs are prerequisite for the formulation and implementation of VOC related air pollution control measures and strategies. Source apportionment may also help to identify potential oilfield in a location through obtaining the concentrations of the tracers. Previous research suggests that high ozone $\left(\mathrm{O}_{3}\right)$ production rates in many locations are strongly associated with high anthropogenic VOC emissions [2-3]. Hence, effort has been made to identify and quantify source emissions of VOCs in different cities and regions so that photochemical air pollution could be controlled [4-5]. Receptor-oriented source apportionment models are the main tools for the source identification of pollutants and the estimation of source contributions to pollutant concentrations. The most widely used models are the Chemical Mass Balance (CMB) [4], Principal Component Analysis (PCA)/Absolute Principal Component Scores (APCS) [5], Positive Matrix Factorization (PMF) [6], and Graphical Ratio Analysis for Composition Estimates (GRACE)/Source Apportionment by Factors with Explicit Restriction (SAFER), incorporated in the UNMIX model [7]. Watson et al. [4] reviewed VOC source apportionment by CMB in more than 20 urban areas. Gasoline vehicle exhaust, liquid gasoline, and gasoline evaporation contributed over $50 \%$ of the ambient VOCs in many of these studies. Vega et al. [8] estimated VOC source apportionment in Mexico City in 1996-1997 and reported that vehicle exhaust made contribution of 54.9-63.8\% and handling and distribution of Liquefied Petroleum Gas (LPG) 20.0-28.5\%. Sosa et al. [9] re-conducted source apportionment in Mexico City using VOC data collected in 20002001 and found that handling and distribution of LPG was the major source (42-52\%), followed by vehicle exhaust (25-28\%), asphalt works (12-14\%) and cooking (5-10\%). In Houston, refinery (26-35\%), petrochemical and evaporative emissions $(20-22 \%)$ and natural gas (13-17\%) were the dominant sources of VOCs in 2003, while the major VOC sources in 2006 became natural gas/crude oil (32-39\%), LPG (26\%), fuel evaporation (20-23\%) and vehicular exhausts (11-13\%). All these studies have provided robust results for VOCs in the study areas.

The Pearl River Delta (PRD) is situated on the southern China coast and is now home to approximately 40 million inhabitants. It is also a major industrial base in southern China. Due to rapid economic development and increased energy use in the past two decades, the amount of major air pollutants emitted to the atmosphere is believed to be increasing significantly, with evidence for higher $\mathrm{O}_{3}$ levels and lower visibility on a regional scale. Previous studies $[5,10]$ have shown complex VOC sources and their contributions in this region. Guo et al. $[5,10]$ revealed that vehicular emissions (39-48\%), solvent use (32$36 \%)$ and LPG/natural gas usage (11-19\%) were the dominant sources in 2000-2002 in Hong Kong, whereas the major VOC sources in inland PRD were industrial emissions (43\%), vehicular emissions (32\%) and biomass burning (25\%). However, in 2004, vehicular emissions (>50\%) became the most important source of VOCs in inland PRD due to the significant increase in vehicles, and solvent use accounted for $33 \%$ of the total VOCs [11].

In recent years, due to industrial restructure and recognition of adverse impact of VOCs on visibility reduction and human health by local governments, VOC sources and their contributions to ambient VOCs in this region may have been significantly revised. Indeed, to reduce VOC emissions, the Hong Kong government has implemented, and the Guangdong government has proposed control measures to recover petrol vapor released during petrol unloading and refueling at petrol stations, and to tighten emissions standards of motor vehicles in line with the European Union standards. The VOC Regulation, effective from 1 April 2007 under the Air Pollution Control Ordinance in Hong Kong, controls the VOC content in 51 types of architectural paints/coatings, 7 types of printing inks and 6 broad categories of consumer products; and requires emission reduction devices to be installed on certain printing machines. The regulation was amended in October 2009 to extend the control to other products with high VOC content, including adhesives, sealants, vehicle refinishing paints/ coatings, and marine vessel and pleasure craft paints/coatings, starting from 1 January 2010 in phases. On the other hand, inland PRD has shifted its emphasis from light industry in early 1990s to heavy industry featuring hi-tech electronic equipment and machinery, chemical products and autos in recent years. Hence, in order to efficiently mitigate photochemical air pollution in the study region, it is crucial to obtain updated VOC emission sources and their contributions. In a recent study, we found that the major sources identified in the region were vehicular emissions, solvent use and biomass burning, whereas extra sources found in inland PRD included liquefied petroleum gas and gasoline evaporation. In Hong Kong, the vehicular emissions made the most significant contribution to ambient VOCs ( $48 \pm 4 \%$ ), followed by solvent use ( $43 \pm 2 \%)$ and biomass burning $(9 \pm 2 \%)$. In inland PRD, the largest contributor to ambient VOCs was solvent use (46 $\pm 1 \%)$, and vehicular emissions contributed $26 \pm 1 \%$ to ambient VOCs [6] The percentage contribution of vehicular emission in Hong Kong in

*Corresponding author: Hai GUO, Air Quality Studies, Department of Civil and Environmental Engineering, The Hong Kong Polytechnic University, Hong Kong, Tel: +852 3400 3962; Fax: +852 2334 6389; E-mail: ceguohai@polyu.edu.hk

Received September 22, 2012; Accepted September 22, 2012; Published September 26, 2012

Citation: Hai GUO (2012) Source Apportionment of Ambient Volatile Organic Compounds from Petroleum and Non-Petroleum Emissions. J Pet Environ Biotechnol 3:e112. doi:10.4172/2157-7463.1000e112

Copyright: ( 2012 Hai GUO. This is an open-access article distributed under the terms of the Creative Commons Attribution License, which permits unrestricted use, distribution, and reproduction in any medium, provided the original author and source are credited. 
Citation: Hai GUO (2012) Source Apportionment of Ambient Volatile Organic Compounds from Petroleum and Non-Petroleum Emissions. J Pet Environ Biotechnol 3:e112. doi:10.4172/2157-7463.1000e112

2007 is close to that obtained in 2001-2003, whereas in inland PRD the contribution of solvent use to ambient VOCs in 2007 was at the upper range of the results obtained in previous studies and twice the 2006 PRD emission inventory. The findings advanced our knowledge of ozone precursors in the PRD region.

\section{References}

1. Russell A, Milford J, Bergin MS, McBride S, McNair L, et al. (1995) Urban ozone control and atmospheric reactivity of organic gases. Science 269: 491-495

2. Ryerson TB (2003) Effect of petrochemical industrial emissions of reactive alkenes and NOx on tropospheric ozone formation in Houston, Texas, J Geophys Res Atm 108: 4249.

3. So KL, Wang T (2004) C3-C12 non-methane hydrocarbons in subtropical Hong Kong: spatial-temporal variations, source-receptor relationships and photochemical reactivity. Sci Total Environ 328: 161-174.

4. Watson JG, Chow JC, Fujita EM (2001) Review of volatile organic compound source apportionment by chemical mass balance. Atmos Environ 35: 15671584.

5. Guo H, So KL, Simpson IJ, Barletta B, Meidarni S, et al. (2007) C1-C8 volatile organic compounds in the atmosphere of Hong Kong: overview of atmospheric processing and source apportionment. Atmos Environ 41: 1456-1472.
6. Guo H, Cheng HR, Ling ZH, Louie PKK, Ayoko G (2011) Which emission sources are responsible for the volatile organic compounds in the atmosphere of Pearl River Delta? J Hazard Mater 188: 116-124.

7. Olson DA, Norris GA, Seila RL, Landis MS, Vette AF (2007) Chemical characterization of volatile organic compounds near the World Trade Center: ambient concentrations and source apportionment. Atmos Environ 41: 56735683.

8. Vega E, Mugica V, Carmona R, Valencia E (2000) Hydrocarbon source apportionment in Mexico City using the chemical mass balance receptor model. Atmos Environ 34: 4121-4129.

9. Sosa ER, Humberto BA, Violeta MA, Pablo SA, Emma BL, et al. (2009) Levels and source apportionment of volatile organic compounds in southwestern area of Maxico City. Environ Pollut 157: 1038-1044.

10. Guo H, Wang T, Blake DR, Simpson IJ, Kwok YH, et al. (2006) Regional and local contributions to ambient non-methane volatile organic compounds at a polluted rural/coastal site in Pearl River Delta, China. Atmos Environ 40: 2345 2359.

11. Liu Y, Min Shao, Sihua Lu, Chih-Chung Chang, Jia-Lin Wang, et al. (2008) Source apportionment of ambient volatile organic compounds in the Pearl River Delta, China: Part II. Atmos Environ 42: 6261-6274. 